\title{
Nové perspelktivy starého kanálu - editorial
}

\author{
Lukáš Nalos ${ }^{1,2}$ \\ 'Ústav fyziologie LF v Plzni UK \\ ${ }^{2}$ Biomedicínské centrum LF v Plzni UK
}

Komentář k | Editorial on

Šatková J et al. Funkční význam hERG: od fyziologické role po cíl protinádorové terapie. Vnitř Lék 2017; 63(2): 114-123.

Rychlá komponenta opožděného draslíkového proudu $\left(\mathrm{I}_{\mathrm{Kr}}\right)$ je obecně odpovědná za buněčnou repolarizaci. Patří mezi nejintenzivněji studované proudy současnosti. Důvodem je fakt, že blokáda tohoto proudu v srdečních buňkách může vést $k$ prodloužení QT intervalu a následným život ohrožujícím arytmiím. Celá řada léků byla stažena z trhu kvưli tomuto nežádoucímu vedlejšímu efektu. Pokud se při vývoji nových potencionálních léků prokáže významný I $I_{\mathrm{kr}}$ blok, vývoj léku je většinou ukončen. Obrovským problémem je ale fakt, že podle odhadů 75-86 \% látek blokuje $\mathrm{I}_{\mathrm{Kr}}$ [1]. Je třeba však podotknout, že signifikantní blok je pozorován často v koncentracích, které přesahují běžné terapeutické hodnoty.

Donedávna se většina vědeckých prací zabývala funkcí $\mathrm{I}_{\mathrm{Kr}} \mathrm{v}$ srdeční elektrogenezi. $\mathrm{V}$ posledních letech se však ukazuje, že kanál Kv11.1 (hERG), který $I_{\mathrm{kr}}$ zprostředkuje, je důležitý v mnoha dalších fyziologických a patologických procesech. Přehledný článek autorek Šatkové a Bébarové [2] shrnuje nejnovější poznatky o kanálu hERG v srdci, nervové tkáni, hladké svalovině, endokrinních buňkách a v nádorových tkáních. Nové poznatky přinášejí celou raadu nových, zajímavých vědeckých otázek.

Především se kanál hERG zdá být velmi slibným polem vědeckého výzkumu jako cíl protinádorové terapie. Vzhledem k tomu, že vysoké procento látek vykazuje $\mathrm{I}_{\mathrm{kr}}$ blok, vyvstávají dva podněty k zamyšlení. První je otázka, jaký vliv má $\mathrm{I}_{\mathrm{kr}}$ blok na účinnost současných protinádorových léků. Může být potenciální $\mathrm{I}_{\mathrm{Kr}}$ blok součástí jejich terapeutického efektu? Z opačného pohledu se pak nabízí otázka, zda vyřazování potenciálních léků $z$ dalšího testování kvůli jejich $\mathrm{I}_{\mathrm{Kr}}$ bloku není v případě protinádorových léků kontraproduktivní. Odpovědi na výše uvedené otázky pak pomohou posoudit perspektivu protinádorové terapie zaměřené na hERG.

Autorky Šatková a Bébarová také ve své práci zmiňují možnosti eliminace nežádoucích účinků $\mathrm{I}_{\mathrm{Kr}}$ bloku na srdeční aktivitu u protinádorových léků, prípadně antidiabetik. Jako momentálně nejdostupnější cestou se zdá být použití látek s kombinovaným účinkem na další srdeční kanály $\left(I_{\mathrm{CaL}^{\prime}}\right.$ Late $\left.\mathrm{I}_{\mathrm{Na}}\right)$, prípadně použití specifických blokátorů těchto kanálů, jež v experimentu vykazují výrazné antiarytmické účinky [3]. Další výzkum $v$ této oblasti může přinést relativně rychle možnost aplikovat $\mathrm{I}_{\mathrm{kr}}$ blokátory $\mathrm{v}$ mimosrdečních indikacích s eliminací jejich nežádoucího účinku na srdce.

Prímá blokáda $\mathrm{I}_{\mathrm{Kr}}$ není jedinou možností, jak ovlivnit tento proud. Především v protinádorové terapii je další zajímavou možností ovlivnění „traffikingu“ hERG proteinu [4]. Přesun kanálových proteinů z místa vzniku do membrány, případně jejich odstranění z membrány je složitý proces, který umožňuje farmakologickou intervencí regulovat množství funkčního proteinu v membráně, a tím zásadně ovlivňovat velikost $\mathrm{I}_{\mathrm{kr}}$. Vzhledem $\mathrm{k}$ předpokládanému většímu obratu proteinů v nádorových buňkách by tento způsob terapie mohl být šetrnější k buňkám zdravým.

\section{Literatura}

1. Hoffmann P, Warner B. Are hERG channel inhibition and QT interval prolongation all there is in drug-induced torsadogenesis? A review of emerging trends. J Pharmacol Toxicol Methods 2006; 53(2): 87-105.

2. Šatková J, Bébarová M. Funkční význam hERG: od fyziologické role po cíl protinádorové terapie. Vnitř Lék 2017; 63(2): 114-123.

3. Bourgonje VJ, Vos MA, Ozdemir S et al. Combined $\mathrm{Na}(+) / \mathrm{Ca}(2+)$ exchanger and L-type calcium channel block as a potential strategy to suppress arrhythmias and maintain ventricular function. Circ Arrhythm Electrophysiol 2013; 6(2): 371-379. Dostupné z DOI: <http:// dx.doi.org/10.1161/CIRCEP.113.000322>.

4. van der Heyden MA, Smits ME, Vos MA. Drugs and trafficking of ion channels: a new pro-arrhythmic threat on the horizon? Br J Pharmacol 2008; 153(3): 406-409.

\section{as. MUDr. Lukáš Nalos, Ph.D. $\triangle$ lukas.nalos@lfp.cuni.cz}

Ústav fyziologie a Biomedicínské centrum LF v Plzni UK www.Ifp.cuni.cz

Doručeno do redakce 18. 1. 2017 